\title{
The Role of Gratitude Towards the Resilience Among Late Adolescents Cyberbullying Victims
}

\author{
Anthony Steven ${ }^{1}$ Jessica Chandhika ${ }^{1}$ Naomi Soetikno ${ }^{1 *}$ \\ ${ }^{1}$ Faculty of Psychology, Universitas Tarumanagara, Jakarta 11440, Indonesia \\ "Corresponding author.Email: naomis@fpsi@untar.ac.id
}

\begin{abstract}
The high use of the internet in Indonesia has an impact on the emergence of cyberbullying. Cyberbullying that is currently happening is a problem that must be addressed immediately because so many cyberbullying victims commit suicide because they are not strong enough to face the pressure. For that, it is necessary to have gratitude to make a happier mood which can then minimize the negative feelings it causes. This study used a non-experimental correlational quantitative method involving 403 participants (280 women and 123 men). Participants in this study can be concluded to have a high level of gratitude, in contrast to having a moderate level of resilience. It can be interpreted that the participants of this study have very good life gratitude, but the ability to rise from pressure still needs to be improved. Based on the results of data testing using the linear regression analysis technique $\mathrm{t}-7.821, \mathrm{p}=0.000, \mathrm{R}$ square $=0.132$. The results of this study can be concluded that there is a significant role of gratitude toward the resilience in late adolescents who are victims of cyberbullying.
\end{abstract}

\section{Keywords: Gratitude, Resilience, Adolescence, Cyberbullying}

\section{INTRODUCTION}

Based on a survey of internet users by APJII (Association of Indonesian Internet Service Providers) in 2018 it was found that internet users in the 15-19 age range and 20-24 years old were the most dominant (Haryanto, 2019). According to the age range described above, it can be concluded that the grouping of late adolescence by Santrock [2], which is 18-21 years old, belongs to the most internet user age range in Indonesia. Balakrishnan [3], Draucker \& Martsolf [4], Machimbarrena et al. [5], and Rahayu [6] explain that the excessive use of the internet can lead to online aggression namely cyberbullying. In adolescence, prone to experiencing cyberbullying [7] because there is still uncontrolled emotional turmoil, weak behavior control [8] and development of thinking and problem-solving has not developed properly [2].

Cyberbullying can be defined as a behavior that carried out secretly against victims that can be done alone or in groups to hurt someone and has a motive to disturb the victim with his actions [9], which is repetitive with the motive of provoking anger, harassing, humiliating, and disturbing the victim [10]. [11] explain that cyberbullying is a global phenomenon that often arises and has a high prevalence. According to APJII (Association of Indonesian Internet Service Providers) (quoted in The Jakarta Post, 2019) in Indonesia, $49 \%$ of the 5900 internet users have experienced cyberbullying. [10] the following are forms of cyberbullying: (1) Spread fake news by taking advantage of other people's identities, (2) using inappropriate words to hurt someone else's feelings, and (3) intimidating others, isolating the victim, and coercing them into doing sexual things.

Megan Meier Foundation (2020) explain there are at least four causes of cyberbullying, (1) it can embarrass others in public so that victims will feel more embarrassed, (2) raise more concern because of the identity of the perpetrator that cannot be traced, (3) control of the dominant perpetrator and (4) victims often feel hopeless because the posts that are distributed cannot be traced and the latter has a very embarrassing impact on the victim because the post is only observed by others without a helping hand. Many negative emotions arise from cyberbullying such as shame, fear, trauma to feelings of hopelessness [14] which then ends with committing suicide [15]. This is confirmed by previous research by Young et al. [16] $97.3 \%$ of the main causes of suicide were due to being a victim of bullying or cyberbullying.

To suppress negative emotions that are felt due to being a victim of cyberbullying, one way that can be done is to apply gratitude. A recent study by Lin [17] and Rey et al. [18] found people with good gratitude levels have fewer suicidal thoughts. According to Breen et al. [19] and Dewall et al. [20] gratitude have several important roles in life, the first is as an indicator of aggression where someone who has good gratitude tends to have low aggression, the second is an indicator of happiness. It can be explained that someone who is always grateful has a happier mood, and can create good quality friendships so that they can minimize the risk of becoming a victim of cyberbullying and increased resilience because they get support from peers [21]. 
Resilience can be defined as a form of strength that is in a person to be able to bounce back from an unpleasant event [22]. Reich et al. [23] added that resilience is an ability that results from a certain process. It can be concluded that resilience is the ability to understand problems which then proceed until someone can rise from pressure. Resilience is very crucial because it relates to how a person survives and adapts to the problems at hand [24], and can suppress the effects of cyberbullying such as reducing stress levels due to feeling [25]. The role of resilience can be explained as a process of forming oneself to be much better and stronger [26].

The relationship between gratitude and resilience can be explained as follows, resilience is important for victims of cyberbullying as a self-defense mechanism from decreased life satisfaction and symptoms of depression [27]. Although resilience can be self-defense against the pressure or stress caused, it is also necessary to have gratitude to increase inner strength and emotional resilience (Chowdhury, 2020). According to Rey et al. [18] that victims of bullying with a good level of gratitude have a low tendency to criticize and blame themselves so that they can become resilient individuals. Someone who instills gratitude has more controlled emotions and can adjust emotions so that it affects the quality of the friendships that are formed [21]. Also, gratitude has a function to build a good social life so that it has an impact on increasing peer support [29].

Based on this explanation, gratitude can build a good social life so that it creates peer support that makes a person resilient, on the other hand, resilience is also formed from peer support which is the output of gratitude. Therefore, departing from the background of this problem makes researchers interested in further examining whether there is a relationship between gratitude and resilience in late adolescents who are victims of cyberbullying.

\section{LITERATURE STUDY}

\subsection{Gratitude}

According to Bono et al. [30] and McCullough et al. [31] gratitude means a feeling or emotional reaction that is received and felt personally as a result of a direct response which is due to the acceptance of something that is a gift which then a person feels the benefits or gains. [32] In adolescence, it is believed that a person will develop his gratitude in line with various existing factors such as personal factors and environmental factors. This development is also influenced by the social relationships that exist at this time, which includes peers, family, school, which in this connection will be a personal uniqueness in expressing the gratitude that is owned because each of them has their own unique experiences.

\subsection{Resilience}

Resilience is the strength of a person with the ability to return to being a strong person or be able to stand back up and recover from an incident that happened to someone so that it has an impact on the occurrence of pressure or stress [33]. Increasing resilience in individuals who are related to stress that a person must be able to accept all forms of events he has experienced at a certain time that has occurred, even though the individual has to understand his situation that he is currently dealing with the situation [34].

\subsection{Late Adolescence}

Late adolescence is a developmental stage marked by a transition period from childhood to adulthood with an age range of 18 years to 21 years [2]. This transitional period was also marked by changes in adolescents to become more independent [35]. At this stage, someone will use formal operational thought more by starting its development at the age of 11-15 years, this theory is Piaget's theory of cognitive development, which is characterized by someone being able to think abstractly and logically [36].

Increasing access to excessive and uncontrolled internet use can increase the risk of cyberbullying, especially among adolescents. During adolescence, there is cognitive development in making a decision, but often the decisions taken are risky (Steinberg quoted in Santrock, 2011). Decision making that is risky to adolescents can be proven by the desire to commit suicide in adolescence because they are unable to face the psychological pressure caused by cyberbullying such as shame, fear, or others that interfere with comfort (Putra, 2019). Olweus [27] revealed that resilience is important for victims of cyberbullying as a self-defense mechanism from decreased life satisfaction and symptoms of depression. Although resilience can be self-defense against the pressure or stress caused, it is also necessary to have gratitude to increase inner strength and emotional resilience (Chowdhury, 2020). Based on this explanation, gratitude can build a good social life so that it creates peer support that makes a person resilient, on the other hand, resilience is also formed from peer support which is the output of gratitude.

\section{METHODS}

\subsection{Research Design}

This research design is non-experimental correlational, in this study has 2 variables, namely gratitude and resilience. Quantitative research methods have an understanding that the data generated is in the form of numbers or numerical. This study will collect data from participants who are involved in this study, which is then coded and analyzed using Statistical Program and Service Solution (SPSS) 
which in turn will clarify a phenomenon being tested with the population taken to be able to generalize.

\subsection{Participants}

Participants in this study were 403 adolescents (280 women and 123 men) with the sampling technique used in this study was purposive sampling with criteria aged 18-21 years, and had experienced cyberbullying. All participants in this study were obtained online by distributing google form links on several social networking sites.

\subsection{Measures}

Gratitude. This study uses Gratitude Questionnaire - 6 (GQ-6) from McCullough et al. (2002) [37] and because the measuring instrument had never been adapted to Indonesian, the questionnaire was adapted first into Indonesian by the researcher so that it is easily understood by the subject, then the translated measuring instrument will be checked first and pass the expert judgments stage before the questionnaire will be distributed in the google form link for a tryout. Based on the results of the tryout tested on 50 participants, the Cronbach alpha value was .736 with an internal consistency value at a good range. This measuring instrument has 6 questions with a scale ranging (1-7), scale 1 can be interpreted as Strongly Disagree, and scale 7 can be interpreted as Strongly Agree. In conducting the scoring of this study, the measuring instrument maker provided information that in item 3 and item 6 the scoring must be done oppositely.

Resilience. This study uses Brief Resilience Scale (BRS) from Smith et al. (2008) [22] and because the measuring instrument had never been adapted to Indonesian, the questionnaire was adapted first into Indonesian by the researcher so that is easily understood by the subject, then the translated measuring instrument will be checked first and pass the expert judgments stage before the questionnaire will be distributed in the google form link for a tryout. Based on the results of the tryout tested on 50 participants, the Cronbach alpha value was .572 , then the researcher decided by eliminating one invalid item so that the Cronbach alpha value increased significantly to .753 , and it can be said that the research instrument became reliable. This measuring instrument has 5 questions with a scale ranging (1-5), scale 1 can be interpreted as Strongly Disagree, and scale 5 can be interpreted as Strongly Agree. In conducting the scoring of this study, the measuring instrument maker provided information that in item 2,4 , and 6

\section{FINDINGS AND DISCUSSIONS}

Based on data obtained about the sex of research subjects from a total of 403 research subjects, male subjects totalled 123 people $(30.5 \%)$, female subjects totalled 280 people $(69.5 \%)$. Based on data obtained about the age of research subjects from a total of 403 research subjects, subjects aged 18 years amounted to 49 people (12.2\%), subjects aged 19 years amounted to 56 people $(13.9 \%)$, subjects aged 20 years totalled 122 people $(30.3 \%)$, and subjects aged 21 years were 176 people $(43.7 \%)$.

In this study, it was found that victims of cyberbullying who either has close friends or do not have close friends are among the victims of cyberbullying. However, victims of cyberbullying are more dominant in participants who have many close friends, this explains that a large number of close friends still have the risk of experiencing cyberbullying.

Participants in this study were dominated by participants who live together with their parents. The results showed $78.7 \%$, live with their grandparents, and the nuclear family was $2.7 \%$, and $18.6 \%$ live alone. Based on these results, it can be concluded that even though someone lives with parents, they still have the potential and dominant to become a victim of cyberbullying, so in conclusion, both living alone, with grandparents and also with parents have the same opportunity to become victims of cyberbullying. This provides evidence that parents and extended families are also unable to overcome or eliminate cyberbullying experienced by children.

The data for gratitude using a scale 1-7 has a mean hypothetical measuring instrument that is 4 while the empirical mean is 5.4198. The empirical mean score is greater than the hypothetical mean score so the subject's gratitude can be concluded to be high. The data picture for resilience using scale 1-5 has a hypothetical mean of measuring instruments that is 3 while the empirical mean is 3.0268 . The empirical mean score is slightly greater than the hypothetical mean score so that the subject resilience can be said to be moderate.

The hypothesis in this study which states that there is a significant role of the gratitude toward the resilience is proven correct and can be proven by the results of the $\mathrm{t}=$ 7.821 and $p=0.000<0.01, \mathrm{R}$ square $=0.132$. These result means that gratitude has $13.2 \%$ significant role toward the resilience. This hypothesis is based on several previous studies conducted by Estria [38], Saputra and Fauziah [39], Reswara [40], Atmadja [41] and Shabrina et al. [42] who also have the same result that there is a relationship between gratitude and resilience. However, there are differences in the results of research by Reswara [40] and research conducted by Estria [38] The results in study of gratitude affect the resilience of $59 \%$ which can be classified as high, while in Estria (2018) study it affects the resilience of only $12.96 \%$ which can be classified as low.

In this study there are several limitations, namely as follows, (a) the participants in this study were only limited to the scope of late adolescents who were only 18-21 years old, which could be said that the age range was a shortage range and could not represent all adolescents in Indonesia, (b) the measuring instrument used is a standard measuring tool, but when a translation is carried out and a tryout is carried out there is an invalid statement item, this may be due to a translation in that item which the participants may not understand, (c) the approach in this study is only a non-experimental quantitative approach that only focuses on whether there is a role between the variable gratitude 
and resilience in late adolescents who are victims of cyberbullying, (d) Future research is expected to be able to further examine what variables have a greater influence on resilience because it is not only gratitude that affects resilience.

\section{CONCLUSIONS}

The results of this study can be concluded that there is a significant role between gratitude and resilience in late adolescents who are victims of cyberbullying. This study proves that gratitude only has a small effect on resilience with a result of only $13.2 \%$ which is more or less the same as the research conducted by Estria [38]. This research was conducted to complement the previous research because there was no similar study.

The level of gratitude in women is higher than men, which is thought to be influenced by many things, such as personal factors, including communication and interaction with others, which are thought to be more active in interacting and communicating with others. The process of gratitude is not instantaneous, but researchers suggest making a list of things that you can be grateful for and from that list make it a reinforcement in yourself to live your life.

\section{REFERENCES}

[1] Haryanto A. T, Pengguna internet Indonesia didominasi milenial. Detik, 2019. Retrieved on https://inet.detik.com/telecommunication/d-4551389/ pengguna-internet-indonesia-didominasi-milenial

[2] Santrock, J.W, Life span development, 2011. McGraw-Hill.

[3] Balakrishnan, V, Cyberbullying among young adults in Malaysia: The roles of gender, age and Internet frequency. Computers in Human Behavior, 46, (2015) 149-157. DOI: https://doi.org/10.1016/j.chb. 2015.01.021

[4] Draucker, C. B., \& Martsolf, D. S, The role of electronic communication technology in adolescent dating violence. Journal of Child and Adolescent Psychiatric Nursing, 23(3), (2010) 133-142. DOI: https://doi.org/10.1111/j.1744-6171.2010.00235.x

[5] Machimbarrena, J. M., Calvete, E., FernándezGonzález, L., Álvarez-Bardón, A., Álvarez-Fernández, L., \& González-Cabrera, J, Internet risks: An overview of victimization in cyberbullying, cyber dating abuse, sexting, online grooming and problematic internet use. International Journal of Environmental Research and Public Health, 15(11), (2018) DOI: https://doi.org/10. 3390/ijerph15112471
[6] Rahayu, F. S, Cyberbullying sebagai dampak negatif penggunaan teknologi informasi. Journal of Information Systems, 8(1) (43), (2012), 22-31.

[7] Jalal, N. M., Idris, M., \& Muliana, M, Faktor-faktor cyberbullying pada remaja. IKRA-ITH HUMANIORA: Jurnal Sosial dan Humaniora, 5(2), (2020), 1-9.

[8] Papalia, D. E., Olds, S. W., \& Feldman, R. D, Human development, 2009. (10 ${ }^{\text {th }}$ Ed). McGraw-Hill.

[9] Tokunaga, R. S, Following you home from school: A critical review and synthesis of research on cyberbullying victimization. Computers in Human Behavior, 26(3), (2010), 277-287. DOI: https://doi.org/ 10.1016/j.chb.2009.11.014

[10] United Nations Children's Fund, Cyberbullying: Apa itu dan bagaimana cara menghentikannya. United Nations Children's Fund, 2020. Retrieved on https://www.unicef.org/indonesia/id/child-protection/ apa-itu-cyberbullying\#question 1

[11] Olweus, D, Cyberbullying: An overrated phenomenon? European journal of developmental psychology, 9(5), (2012), 520-538.

[12] The Jakarta Post, Half of all netizens in Indonesia victims of cyberbullying: Study. The Jakarta Post, 2019. Retrieved on https://www.thejakartapost.com/ life/2019/05/16/half-of-all-netizens-in-indonesiavictims-of-cyberbullying-study.html

[13] Megan Meier Foundation, Causes of cyberbullying. Megan Meier Foundation, 2021. Retrieved on https://www.meganmeierfoundation.org/ cyberbullying

[14] Badan Siber dan Sandi Negara, Cara mengatasi cyberbullying, 2020. Badan Siber dan Sandi Negara. Retrieved on https://bssn.go.id/cara-mengatasicyberbullying/

[15] Putra, E. N, Merunut lemahnya cyberbullying di Indonesia. American Indonesian Exchange Foundation, 2019. Retrieved on https://www.aminef.or.id/ merunut_lemahnya_hukum_cyberbullying_di_indonesi a/\#: :text=Data\%20kasus\%20 cyberbullying\%20di\%20I ndonesia,bullying\%20mencapai\%2022\%2C4\%25.

[16] Young, R., Subramanian, R., Miles, S., Hinnant, A., \& Andsager, J. L, Social representation of cyberbullying and adolescent suicide: A mixed-method analysis of news stories. Health Communication, 32(9), (2017), 1082-1092. DOI: https://doi.org/10.1080/ 10410236.2016.1214214 
[17] Lin, C. C, The relationships among gratitude, selfesteem, depression, and suicidal ideation among undergraduate students. Scandinavian Journal of Psychology, 56(6), (2015), 700-707. DOI: https://doi. org/10.1111/sjop.12252

[18] Rey, L., Quintana-Orts, C., Mérida-López, S., \& Extremera, N., Being bullied at school: Gratitude as potential protective factor for suicide risk in adolescents. Frontiers in Psychology, 10(3), (2019), 110. DOI: https://doi.org/10.3389/fpsyg.2019.00662

[19] Breen, W. E., Kashdan, T. B., Lenser, M. L., \& Fincham, F. D, Gratitude and forgiveness: Convergence and divergence on self-report and informant ratings. Personality and Individual Differences, 49(8), (2010) 932-937.DOI: https://doi.org/10.1016/j.paid.2010.07. 033

[20] Dewall, C. N., Lambert, N. M., Pond, R. S., Kashdan, T. B., \& Fincham, F. D, A grateful heart is a nonviolent heart: Cross-sectional, experience sampling, longitudinal, and experimental evidence. Social Psychological and Personality Science, 3(2), (2012) 232-240. DOI: https://doi.org/10.1177/ 1948550611416675

[21] Alkozei, A., Smith, R., \& Killgore, W. D. S, Grateful people are happy and healthy-But why? Frontiers for Young Minds, 5, (2017), 1-9. DOI: https://doi.org/10.3389/frym.2017.00055

[22] Smith, B. W., Dalen, J., Wiggins, K., Tooley, E., Christopher, P., \& Bernard, J, The brief resilience scale: Assessing the ability to bounce back. International Journal of Behavioral Medicine, 15(3), (2008), 194200. DOI: https://doi.org/10.1080/10705500802222972

[23] Reich, J. W., Zautra, A., \& Hall, J. S, Handbook of adult resilience, 2012. The Guilford Press.

[24] García-León, M. Á., Pérez-Mármol, J. M., Gonzalez-Pérez, R., García-Ríos, M. del C., \& PeraltaRamírez, M. I, Relationship between resilience and stress: Perceived stress, stressful life events, HPA axis response during a stressful task and hair cortisol. Physiology and Behavior, 202(2), (2019) 87-93. DOI: https://doi.org/10.1016/j.physbeh.2019.02.001

[25] Hinduja, S., \& Patchin, J. W, Cultivating youth resilience to prevent bullying and cyberbullying victimization. Child Abuse and Neglect, 73(9), (2017), 51-62. DOI: https://doi.org/10.1016/j.chiabu.2017.09. 010

[26] Suryadi, D, Melenting Menjadi Resilien, 2018. Penerbit Andi.
[27] Santos, D., Mateos-Pérez, E., Cantero, M., \& Gámez-Guadix, M, Cyberbullying in adolescents: Resilience as a protective factor of mental health outcomes. Cyberpsychology, Behavior, and Social Networking, (2020). DOI: https://doi.org/10.1089/ cyber. 2020.0337

[28] Chowdhury, M. R, The neuroscience of gratitude and how it affects anxiety \& grief. Positive Psychology, 2020. Retrieved on https://positivepsychology.com/ neuroscience-of-gratitude/

[29] Jans-Beken, L., Jacobs, N., Janssens, M., Peeters, S., Reijnders, J., Lechner, L., \& Lataster, J, Gratitude and health: An updated review. The Journal of Positive Psychology, 15(6), (2020), 743-782. DOI: https:// doi.org/10.1080/17439760.2019.1651888

[30] Bono, G., Emmons, R. A., \& Mccullough, M. E, Gratitude in practice and the practice of gratitude. Positive Psychology in Practice, (2012), 464-481. DOI: https://doi.org/10.1002/9780470939338.ch29

[31] McCullough, M. E., Kimeldorf, M. B., \& Cohen, A. D, Current directions in psychological science an adaptation for altruism gratitude. SAGE Open. (2008). DOI: https://doi.org/10.1111/j.1467-8721.2008.00590.x

[32] Emmons, R. A., \& Mccullough, M. E, The psychology of gratitude, 2004. Oxford University Press.

[33] Smith, B. W., Tooley, E. M., Christopher, P. J., \& Kay, V. S, Resilience as the ability to bounce back from stress: A neglected personal resource? Journal of Positive Psychology, 5(3), (2010), 166-176. DOI: https://doi.org/10.1080/17439760.2010.482186

[34] Prince-Embury, S., \& Saklofske, D. H, Resilience in children, adolescents, and adults: Translating research into practice, Springer, (2013). DOI: https://doi.org/10.1007/978-1-4614-4939-3

[35] Soetikno, N., \& Arimurti, D, Role of self-concept and conformity on bullies. International Conference on Progressive Education (ICOPE 2019), (2020), 299-311. Atlantis Press.

[36] Santrock, J. W., Adolescence, 2016. McGraw-Hill.

[37] McCullough, M. E., Emmons, R. A., \& Tsang, J, The grateful disposition: A conceptual and empirical topography. Journal of Personality and Social Psychology, 82, (2002), 112-127.

[38] Estria, R. T, Hubungan antara kebersyukuran dan resiliensi pada masyarakat di daerah rawan bencana, Thesis. Universitas Islam Indonesia, 2018. 
[39] Saputra, D. A., \& Fauziah, N, Hubungan antara kebersyukuran dengan resiliensi pada mahasiswa bidikmisi fakultas ekonomika dan bisnis Universitas Diponegoro, Thesis. Universitas Diponegoro, 2019.

[40] Reswara, A. M. D, Hubungan antara kebersyukuran dan resiliensi pada ibu yang memiliki anak berkebutuhan khusus, Dissertation. Universitas Islam Indonesia, 2019.

[41] Atmadja, A. A. S, Hubungan antara gratitude dan resiliensi pada remaja dengan single parent, Dissertation. Universitas Pelita Harapan, 2020.

[42] Shabrina, K., Kusristanti, C., \& Listiyandini, R. A, Gratitude and resilience among adolescents who have experienced parental divorce. Psychological Research on Urban Society, 3(1). (2020) DOI: https://doi.org/10. 7454/proust.v3i1.59. 